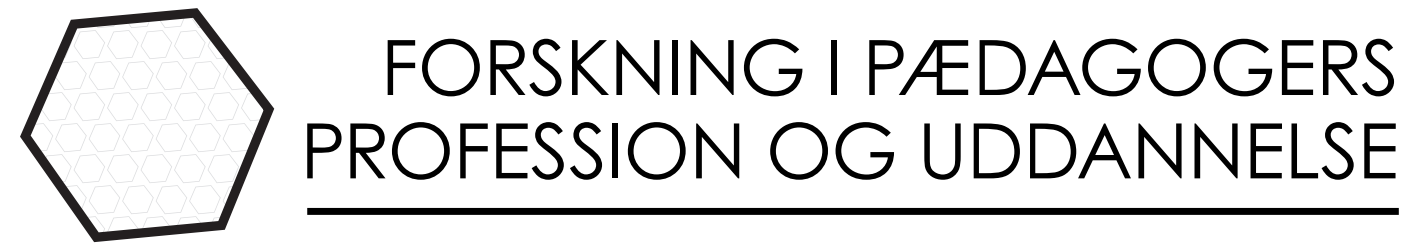

\title{
Handicap som vanskeliggjort deltagelse
}

\section{Christina Holm Poulsen}

Lektor, Ph.d., UC SYD

Mail: chpo@ucsyd.dk 


\title{
Resume
}

Med udgangspunkt i en case, der omhandler pigen Sofies deltagelse i skolen, problematiseres tendensen til, at lærere og pædagoger forstår Sofies deltagelsesvanskeligheder i lyset af en handicapkategori. Casen om Sofie bidrager med praksisnær viden om, hvordan handicap i form af en diagnose får betydning for Sofies deltagelse i skolens faglige og sociale fællesskaber. I artiklen præsenteres en forståelse af fællesskaber som en 'fælles skabelse', og der peges i den forbindelse på, at det pædagogiske arbejde $\mathrm{i}$ forhold til mennesker med handicap retter sig mod processer i fælles-skabelsen med fokus på inddragelse, indflydelse og vordighed.

\begin{abstract}
Based on a case concerned with the girl Sofie's participation in school, the article problematizes the tendency that teachers and educators understand Sofie's difficulties through a disability category. The case about Sofie provides practical knowledge of how disability, in form of a diagnosis, appears to be important for Sofie's participation in professional and social communities in school. The article presents an understanding of communities as a 'community creation', and it points out that the pedagogical work in relation to people with disabilities is to concern itself with processes in the community with focus on involvement, influence and dignity.
\end{abstract}

\section{Keywords}

Participation difficulties, disability, school, community, involvement, dignity.

\section{Nøgleord}

Deltagelsesvanskeligheder, handicap, skole, fælles-skabelse, inddragelse, værdighed. 


\section{Indledning}

I de senere år har der været en stigende anvendelse af psykiatriske diagnoser som forklaring på de vanskeligheder, børn møder i institutionelle sammenhænge (Harwood \& Allan 2014, Hjörne \& Säljö 2004, Nielsen \& Jørgensen 2010). Den øgede diagnosticering har skabt efterspørgsel på viden om specifikke diagnoser, der forstås som en forudsætning for at hjælpe børn i vanskeligheder. Ærindet med nærværende artikel er imidlertid ikke at sætte anvendelse af diagnoser til diskussion eller problematisere den øgede tendens til diagnosticering. Hensigten er i stedet at "overgå diagnosen og skabe viden på stedet", som Ole V. Rasmussen formulerer det i en opfordring til at udforske, hvordan vanskeligheder knytter sig til konkrete forhold og forløb i praksis (Rasmussen 2009). I artiklen vil jeg illustrere, hvordan en udforskning af hverdagssituationer i skolen kan bidrage med praksisnær viden, der overgår diagnosens abstrakte og kontekstfrie sprogbrug.

I artiklen har jeg fokus på pigen Sofie, som jeg følger fra midten af 2. til midten af 4. klasse. I løbet af de to år bliver det tiltagende vanskeligt for Sofie at skabe sig adgang til klassens fællesskaber både i frikvartererne og i undervisningen. Sofie har diagnosen 'infantil autisme', og der en tendens til, at skolens voksne forstår deltagelsesvanskelighederne i lyset af den pågældende diagnose. Klasselæreren peger på, at det kræver viden om diagnose for at kunne håndtere de vanskeligheder, Sofie oplever i sit skoleliv. Når jeg følger Sofie i løbet af en skoledag, bliver det tydeligt, at vanskelighederne knytter sig til konkrete forhold i skolen, som det er vanskeligt at begribe med et diagnosevokabularium, da diagnoser er for abstrakte og lukkede til at begribe den kontekst, som børnene er i (Hertz 2010, Rasmussen 2009). På den baggrund vil jeg ikke gå nærmere ind i den specifikke diagnose, men i stedet fokusere på situationer og processer i skolen, som Sofies vanskeligheder må forstås i lyset af.

Jeg vil i artiklen argumentere for to pointer. Den første pointe handler om, at diagnosen ser ud til at blive forklaring på deltagelsesmåder, der kan forekomme anderledes, frem for at det 'anderledes' blive sat i sammenhæng med situationer, hvor nogle mennesker bliver mødt på måder, hvor de gøres anderledes. Artiklens anden pointe er, at i forhold til mennesker med vanskelige deltagelsesbetingelser, må det pædagogiske arbejde rette sig mod at skabe fællesskaber, hvor den enkelte oplever at blive inddraget $i$ og få indflydelse på fælles-skabelsen, og hvor den enkeltes bidrag bliver mødt på værdige måder.

\section{Deltagelsesvanskeligheder}

Casen om Sofie stammer fra et fornyeligt afsluttet ph.d.-projekt (Holm Poulsen 2017), der gennem brug af deltagerobservation informeret af den kritisk psykologiske praksisforskning (Dreier 1996, Højholt 2005, Højholt \& Kousholt 2012) har udforsket deltagelsesvanskeligheder i skolen fra et analytisk børneperspektiv. At anvende et analytisk børneperspektiv er en bestræbelse på at udforske, hvordan 
det, der sker, ser ud og har betydning for børnene (Højholt 2005). Det er med andre ord en bestræbelse på at se med barnet ud i dets liv og være udforskende på, hvad børn gør og retter sig mod (Røn Larsen 2011).

I forskningsprojektet har jeg fokus på situationer i skolen, hvor børn kommer i vanskeligheder med afsæt i en forståelse af, at vanskelighederne hænger sammen med forhold i praksis. Denne forståelse knytter sig til det teoretiske deltagelsesbegreb, som det formuleres i den kritiske psykologi, hvor mennesker grundlæggende forstås som deltagere i samfundsmæssig praksis (Dreier 2008, Holzkamp 2013, Højholt 2001). Via handlinger skabes, vedligeholdes og ændres den socio-materielle verden, der samtidig udgør betingelser for menneskers handlinger. Der eksisterer således et dialektisk forhold mellem mennesker og verden. Denne dialektik giver blik for, at børns måde at deltage på må forstås i sammenhæng med, hvad deltagelsen er en del af. Som Ole Dreier skriver, så retter deltagelsesbegrebet opmærksomheden mod, at vi kun kan forstå den enkelte persons måde at fungere og udvikle sig på ud fra det, personen er en del af (Dreier 1999).

Jeg anvender begrebet 'deltagelsesvanskeligheder' for at fastholde deltagelsens dobbeltheden og for at pege på, at det er selve deltagelsen, der er vanskeliggjort. Artiklen lægger sig derved i tråd med den del af handicapforskningen, der forstår handicap som noget, der opstår i mødet mellem den enkelte og samfundet. Denne tilgang benævnes 'den sociale model' og bygger på følgende præmis:

\section{"(...) disability is a difference; disability in and of itself is neutral; disability derives from interaction between the individual and society; the remedy to this problem is to change the interaction between the individual and society." (Loewen \& Polland 2010: 9)}

Denne forståelse adskiller sig fra og er en reaktion på den såkaldte medicinske model, hvis tilgang er, at handicap er mangler og begrænsninger hos den enkelte og derved et individuelt problem (se Kurth 2013 og Loewen \& Polland 2010 for udfoldelse af de forskellige handicapforståelser). Nærværende artikel kan derved læses som et bidrag til og nuancering af den sociale model ved at belyse, hvordan handicap knytter sig til konteksten og måden, den enkeltes handlinger bliver forstået og mødt på i fælles-skabelsen.

\section{Fœlles-skabelse}

I artiklen anvendes den sproglige sammenstilling 'fælles-skabelse', der fungerer som et analytisk perspektiv på menneskers fælles liv med hinanden. Ved at fremskrive fællesskabet som en 'fælles- skaben' understreges det dynamiske og processuelle syn på fællesskaber som noget, der hele tiden skabes, ændres og vedligeholdes gennem deltagernes aktive handlinger rettet mod at skabe og organisere det fælles (Brinkmann 2011, Kousholt 2006). Med fælles-skabelsesbegrebet (Kousholt 2006, Munch 2017) rettes opmærksomheden mod, hvad det fælles er, hvilket Erik Axel (2009) begrebssætter som fælles 'sager', der grundlæggende er 
sammensatte og modsigelsesfulde. Mennesker samarbejder således om modsigelsesfulde sager, der endvidere ser forskellige ud qua det forhold, at mennesker deltager fra forskellige positioner, hvorfra de har et særligt perspektiv på det, der foregår, og forskellige interesser, ønsker og muligheder for at gøre sig gældende (Dreier 1997, 2008). Forståelsen af fællesskabet som en fælles-skabelse overskrider det entydige og harmoniske, hvilket Dorte Kousholt pointerer på følgende måde:

\footnotetext{
"Det er vigtigt her at fremhoeve, at begrebet om foellesskab hverken skal konnotere enhed, enighed eller harmoni. Det er et perspektiv på deltagerne som betingelser for hinanden og medskabere af hinandens muligheder. Det skal forstås både i 'positiv'og 'negativ' forstand - deltagerne $i$ et foellesskab kan bidrage både udvidende og begroensende til hinandens muligheder. "(Kousholt 2006: 32)
}

Fælles-skabelsesbegrebet bidrager til forståelser af, at mennesker ikke alene er deltagere i samfundsmæssig praksis, men at de samarbejder om modsigelsesfulde sager med forskellige muligheder for at gøre sig gældende qua det forhold, at mennesker er positioneret forskelligt.

\section{Ulige deltagelsesmuligheder}

I skolen skal børn deltage i en praksis, der er kendetegnet ved skarpe opdelinger mellem undervisningssituationer rammesat af de voksne og frikvarterernes mere frie situationer. De skarpe opdelinger knytter sig til skolens skemaopdelte hverdag, dens undervisningsopgave og dertilhørende prioritering af de voksnes tilstedeværelse. Når børnene sendes ud til frikvarter, holder lærerne pause, hvilket får den betydning, at børnene står forholdsvis ${ }^{1}$ alene i forhold til at få det sociale liv til at fungere. Adskillelsen mellem på den ene side læring, undervisning og faglighed og på den anden side socialitet, socialt liv og samspil knytter sig til skolens struktur; men ikke til børnelivet. Flere studier peger på, at børn på tværs af skoledagens forskellige situationer er optaget af 'at være med' blandt de andre børn, og at vanskeligheder i de sociale fællesskaber ser ud til at få betydning for børns deltagelse i skolens faglige aktiviteter (Holm Poulsen 2017, Højholt 2001, Morin 2007, Røn Larsen 2011, Stanek 2012). Det er derved en central teoretisk pointe, at børns sociale liv og læring ikke er to adskilte størrelser, men hænger sammen.

Inden børnene slippes ud til frikvarter, er det en tilbagevendende praksis i Sofies klasse, at læreren eller pædagogen koordinerer, hvem der leger med hvem. Denne praksis kan ses i lyset af, at frikvarternes forløb har betydning for den efterfølgende undervisning. Blandt andet fortæller lærerne, at der er en tendens til, at frikvarterernes konflikter tager for meget tid af den faglige undervisning, ligesom det kan være vanskeligt for børnene at koncentrere sig om undervisningen, hvis frikvartererne er for konfliktfyldte. Ofte ser jeg koordineringen tage

1 De voksne, der er med børnene ude, har mest til opgave at holde øje med dem, hvilket også fremgår af betegnelsen 'gårdvagt'. 
form af, at læreren eller pædagogen spørger børnene, hvad de skal lave og med hvem. I andre situationer spørger de ud i rummet, om der er nogen, der mangler en legeaftale. Sofie er næsten altid den, der ikke har nogen at være sammen med, og nogle gange må den voksne presse lidt på for at få børnene til at invitere Sofie med i en leg.

Det er $i$ slutningen af timen, og børnene spiser madpakker. Podagogen spørger, om der er nogen, der har brug for, at der arrangeres en legeaftale. Enkelte børn rakker hånden op, og pcedagogen spørger, hvad de gerne vil lave, og hvem de gerne vil lege med. De fleste børn bliver hurtigt inviteret med $i$ en leg. Sofie kigger lidt rundt og begynder forsigtigt at raekke hånden op, så den lige kan skimtes over hendes hoved. Paedagogen får øje på markeringen og spørger, hvad Sofie gerne vil lave i frikvarteret. Sofie toenker sig lidt om og siger så, at hun gerne vil lege $i$ sandkassen. Henvendt til hele klassen spørger padagogen, om der er nogen, der vil lege sammen med Sofie $i$ sandkassen. Der bliver helt stille $i$ klassen; ingen siger noget. Enkelte børn kigger rundt på de andre, men ingen melder sig. Til sidst henvender poedagogen sig til to piger, der indvilliger $i$, at Sofie gerne må voere med $i$ deres leg.

Sofies tøvende markering kan ses i lyset af, at det ofte er vanskeligt for hende at få etableret en legeaftale for frikvarteret. De manglende invitationer til hende står i skærende kontrast til de muligheder, de andre børn får tilbudt. At få hjælp til at etablere en legeaftale for frikvarteret ser dermed ud til have forskellig betydning for forskellige børn, da det for nogle børn bliver en tydelig markering af, at de er velkomne, mens det for andre forholder sig lige omvendt. Koordineringen af børns lege og relationer rummer derved en dobbelthed, da den pågældende koordinering gøres med henblik på at give børnene lige muligheder for at være med samtidig med, at det er et arrangement, der netop tydeliggør uligheden.

Når Sofie bliver knyttet til en gruppe eller melder sig til en aktivitet, så betyder det ikke i sig selv, at der er tilvejebragt deltagelsesmuligheder, hvor Sofie oplever at blive inddraget i det fælles. Af mine observationer tegner der sig et billede af, at det, der i udgangspunktet skulle være en hjælp, i flere situationer ser ud til at blive en del af problemet og får utilsigtet betydning, hvilket nedenstående observation illustrerer.

Lareren taler med børnene om, hvad de skal lave i det kommende frikvarter. De fleste børn har aftaler, og loereren spørger derfor, om der er nogen, der mangler én. Sofie roekker hånden op, og loereren spørger, om der er nogen i klassen, der vil invitere Sofie med $i$ en leg. Der er stille et stykke tid, indtil Astrid markerer og tilbyder Sofie at voere med til et boldspil sammen med Merete.

Da det ringer ud til frikvarter, viser det sig, at Astrid skal blive i klassen og feje. Merete og Sofie står tavse ved siden af hinanden og venter, indtil Astrid siger, at de bare skal gå ud. Merete begynder at gå, og Sofie folger efter hende. De taler ikke sammen. Sofie forsøger småløbende at komme op på siden af Merete og kommer på et tidspunkt foran hende. Da Sofie er kommet ud på legepladsen, vender hun sig om og opdager, at Merete ikke laengere er bag hende. Hun kigger søgende rundt og får øje på Merete, der scetter sig på en boenk noer ved fodboldbanen. Sofie løber hen til hende, men $i$ det øjeblik Sofie scetter sig, rejser Merete sig for at deltage $i$ fodboldkampen. Senere, da Astrid kommer ud på legepladsen, løber Sofie hen til hende, men Astrid 
begynder at lege med nogle andre, og virker ikke interesseret $i$ at voere sammen med Sofie.

I den pågældende situation blev Sofie inviteret med i en leg, der ikke blev til noget, og det fremstod ret tydeligt, at hverken Merete eller Astrid var interesserede i at være sammen med hende. Sofie efterlades derved i en situation, hvor læreren tror, at problemet er løst, men hvor problemet i høj grad udspiller sig blandt pigerne. I flere situationer oplevede jeg, at Astrid tilbød Sofie at være med, men efterfølgende bemærker jeg, at det er en 'tom' invitation, idet Sofie ikke inddrages i det, de andre børn har sammen.

Det, der udspiller sig blandt pigerne, handler ikke alene om sociale konflikter og børn, der ikke vil hinanden, men om en skole, hvor det forventes, at børn udviser socialt ansvar. Når Astrid på lærerens forespørgsel markerer og derved inviterer Sofie med, så er det en relevant og til dels nødvendig handling i forhold til en lærer, der spørger og afventer, at nogen markerer og inviterer med. Det pågældende koordineringsarrangement fordrer, at nogen åbner op og inviterer med, hvilket er en fordring, Astrid jævnligt tager på sig.

\section{Usynliggørelse}

I løbet af de to år, jeg følger Sofie, oplever jeg, at hun bliver hun mere og mere usynliggjort som mulig legekammerat og samarbejdspartner. Med begrebet 'usynliggørelse' hentyder jeg til en proces, hvor Sofie i stigende grad bliver overset og ignoreret af de andre børn. Et eksempel på dette er en situation, hvor Sofie i billedkunstundervisningen står ved et bord og maler sammen med to andre piger. Sofie står imellem pigerne, men de taler sammen som om, Sofie ikke er til stede. Som observatør får jeg en fornemmelse af, at Sofie nærmest er luft. Pigerne synes ikke at bemærke Sofies stille forsøg på at bidrage til samtale, hvorfor Sofie til sidst opgiver. Sofie deltager ofte på måder, hvor hun fremstår stille, mimikfattig, passiv og med begrænset initiativ til at bidrage til fælles-skabelsen samtidig med, at hun oplever at blive forbigået, fravalgt og overset af de andre. Der forekommer således en dobbelthed og dialektik i usynliggørelsen af Sofie, idet hun bliver overset og ignoreret af de andre samtidig med, at hun deltager på måder, der bidrager til, at hun netop bliver overset og ignoreret.

Det teoretiske deltagelsesbegreb er velegnet til at begribe dette dobbelte forhold, hvor de vanskeligheder, der udvikler sig for Sofie, både må forstås i lyset af hendes måde at deltage på og den kontekst, hvori deltagelsen finder sted. De vanskeligheder, der udvikler sig for Sofie, finder sted i en skole, hvor børn bliver forstået og derigennem mødt forskelligt, og hvor nogle børn forstås mere kategorisk og entydigt end andre (Højholt \& Schwartz 2018). I Sofies klasse er børnene bekendt med, at Sofie har en diagnose inden for autismespektret, og det kan være denne viden, der har betydning for, at de møder hende anderledes. Nedenstående 
observation giver indsigt, hvordan Sofie bliver mødt på måder, hvor hun gøres anderledes.

Børnene har fåt til opgave at konstruere en drage ved brug af plastikposer, pinde, snor og tape. Ida og Marie er optaget af arbejdet, mens Sofie sidder og kigger på det, de laver. Sofie spørger på et tidspunkt, om hun må sctte tape på. De andre nikker. Sofie klipper et stykke tape, men Ida udbryder, at det er alt for lille, og roekker hende et større stykke. Lige inden Sofie placerer tapen, bliver hun irettesat af Marie. Marie tager tapen ud af hånden på Sofie og viser, hvordan det skal vende.

Ida og Marie foreslår, at Sofie skal klippe plastikken til dragen. Sofie klipper og viser arbejdet frem. "Det er fint," siger Ida, mens hun skcever til Marie. "Måske jeg skal gøre det?" siger Marie og tager dragen fra Sofie. Senere spørger Sofie, hvor snoren til dragen skal fastscettes. Marie fortceller, at den skal sidde i enden af dragen, hvortil Sofie svarer, at hun troede, den skulle voere i midten. "Nej, den skal da sidde $i$ enden," svarer Marie.

Da dragen er foerdig, skal den efterprøves udenfor, men det viser sig imidlertid, at den ikke er flyvedygtig, fordi snoren sidder forkert. Placeringen af snoren viser sig at voere et generelt problem $i$ alle grupper, hvorfor børnene til deres store frustration ikke kan få dragerne til at flyve. Lorerne voelger at samle børnene for at drøfte, hvorfor snoren skulle placeres i midten. Mens loererne forklarer, skuler Marie og Ida af og til over på Sofie; men de siger ikke noget.

Senere taler jeg med Sofie om timen og spørger, hvordan det gik med at bygge dragen. Sofie fortceller: "Det gik lidt godt og lidt dårligt. Det gode var, at vi skulle prøve at få den til at flyve. Det dårlig var, at de andre ikke ville høre på, at snoren skulle sidde i midten. Hver gang jeg siger min idé, så siger de bare noget andet, og så gør de noget andet."

Fælles-skabelsesbegrebet gør det muligt at få øje på, hvordan pigerne i den pågældende undervisningssituation aktivt forsøger at skabe og organisere det fælles, som samtidig stiller sig forskelligt, idet pigerne har forskellige muligheder for at gøre sig gældende i fælles-skabelsen. Det fælles, som pigerne er sammen om, er ligeledes ikke entydigt, da det både handler om at præstere fagligt, samarbejde på relevante måder og dermed leve op til undervisningens faglige krav samtidig med, at pigerne er optaget af relationen til hinanden. For Ida og Marie handler dragebygningen ikke alene om at konstruere en flyvedygtig drage, men også om at skabe en flot drage.

I denne fælles-skabelse har Sofie særdeles vanskeligt ved at bidrage og gøre sig gældende. Ida og Marie møder Sofie på måder, hvor hun gøres anderledes, både i form af Ida og Marias blikke til hinanden, deres særlige stemmeføring, når de taler til Sofie, og deres konstante vurdering af hendes arbejde. Sofies bidrag bliver således mødt og evalueret på en anden måde end Ida og Maries. Pigernes forskellige muligheder i fælles-skabelsen illustrerer pointen om, at børnene udgør betingelser for hinandens deltagelse og er medskabere af hinandens muligheder på godt og ondt (Kousholt 2006). Samtidig knytter deres deltagelsesbetingelser sig til en praksis, hvor forskellige forståelser og kategorielle opdelinger er i spil og får betydning for, hvordan det enkelte barn bliver mødt. Den særlig- og usynliggørelse af Sofie, som finder sted i pigernes gruppearbejde, handler ikke alene 
om Ida og Maries måde at være sammen med Sofie på. Det handler bredere set om, at Sofie på tværs af skoledagens forskellige situationer bliver forstået og mødt anderledes end de andre børn, og derigennem bliver hun også gjort anderledes. Samtidig må det 'anderledes' forstås i lyset af, at Sofies måde at deltage på skiller sig ud fra de andre børns deltagelsesmåde, idet hun forholder sig passivt, afventende og resignerende.

\section{Inddragelse, indflydelse og vardighed}

De vanskeligheder, der udvikler sig for Sofie, kan ikke alene begribes med et diagnosevokabularium, men må forstås som knyttet til forhold og forløb i praksis (jf. Rasmussen 2009), hvor Sofies deltagelsesmåde og børnenes måde at møde Sofie på gensidigt betinger hinanden i et dialektisk samspil. Gensidigheden i deltagelsesvanskelighederne peger på, at det pædagogiske arbejde både må rette sig mod den enkeltes deltagelse og fællesskabets måde at fungere på. Deltagelse bliver derved ikke alene et spørgsmål om at voere med, men om måder at voere med på, hvilket peger på nødvendigheden af at arbejde med et differentieret deltagelsesbegreb, der gør det muligt at udforske og forstå forskellige aspekter ved deltagelsen.

Inden for den kritisk psykologiske børneforskning er der arbejdet med at teoretisere børns læring og udvikling som et spørgsmål om at udvikle forudsætninger for at deltage, og dette arbejde har ført til at begrebssætte børns læring og udvikling gennem deres inddragelse $i$, bidrag til og indflydelse på sociale fællesskaber (Højholt 2001, 2016). Begreberne gør det muligt at skærpe blikket for forskellige aspekter ved deltagelsen, og hvad der bliver væsentligt at arbejde med, hvis deltagelsen ikke alene skal have karakter af tilstedeværelse. I den forbindelse finder jeg et begreb om værdighed centralt for at betone det forhold, at det ikke alene handler om muligheden for at bidrage og få indflydelse, men om værdige måder at møde hinanden på i fælles-skabelsen.

Værdighedsbegrebet står centralt i handicapforskningen og kampen for 'social justice' (Loewen \& Pollard 2010), og i nærværende sammenhæng anvender jeg det til at begrebssætte fællesskaber, hvor den enkelte bliver forstået og mødt som et ligeværdigt subjekt, hvis bidrag er værd at forholde sig til og inddrage i fælles-skabelsen. Værdighed knytter sig for mig at se til at møde mennesker som netop mennesker, der handler begrundet i forholde til betingelser i praksis. Ole V. Rasmussen (2009) peger på, at i situationer, hvor der er en diagnose i spil, er der er en tendens til, at årsager til et barns konkrete vanskeligheder bliver begrundet med henvisning til en diagnose frem for, at vanskelighederne bliver forbundet med forhold i praksis.

Igennem artiklens analyser har jeg søgt at tydeliggøre den pointe, at vanskelighederne for Sofie handler om begrænsede muligheder for at få adgang og bidrage til fælles-skabelsen. Denne form for praksisnær viden overgår diagnosens abstrakte og kontekstfrie sprogbrug og peger på væsentlige opmærksomhedspunkter i det daglige pædagogiske arbejde. Eksempler på en sådan pædagogisk opmærksom- 
hed er en situation fra mit feltarbejde, hvor en pædagog sætter sig sammen med Sofie og spiller et brætspil. Flere børn samler sig om spillet, og pædagogen sørger for at inddrage Sofie i den samtale, der udvikler sig blandt børnene. Et andet eksempel er et gruppearbejde, hvor Sofie skal deltage sammen med fem andre børn. Børnene skal drøfte forskellige faglige spørgsmål, hvortil Sofie forsøger at sige noget, men det lader ikke til, at de hører hende. En lærer blander sig og får de andre børn til at lytte til Sofies bidrag. Efterfølgende hjælper læreren med, at Sofies bidrag inddrages i opgaveløsningen.

Sådanne små eksempler giver indsigt i, hvordan pædagoger og lærere kan arbejde med at inddrage Sofie i fælles-skabelsen, og sådanne situationer kunne der sagtens skabes flere af. Det fordrer ikke en særlig viden om en specifik diagnose, men voksne, der involverer sig i det, der er på spil blandt børn og har opmærksomheden rettet mod børns deltagelse og deres forskellige muligheder for at gøre sig gældende i fælles-skabelsen. Det pædagogiske arbejde kan derved siges at rette sig mod den enkeltes deltagelse og fællesskabets måde at fungere på med fokus på inddragelse, indflydelse og værdighed.

\section{Konklusion}

I artiklen har jeg søgt at illustrere, at de vanskeligheder, der udvikler sig for Sofie, knytter sig til vanskelige betingelser i fælles-skabelsen, hvor Sofie bliver mødt anderledes end de andre børn. Den hjælp, lærerne efterspørger for at håndtere de udfordringer, Sofie oplever i skolen, er en viden om diagnosen. Diagnosen ser ud til at centrere og cementere vanskelighederne som knyttet til det individuelle barn frem for, at vanskelighederne bliver forbundet med forhold og forløb i praksis. Det ser ud til, at når deltagelsesvanskeligheder forklares med henvisning til en diagnose, bliver det vanskeligt for lærere og pædagoger at få øje på udviklingsmuligheder i praksis, og de kan på den baggrund komme til at overse dynamikker, der medfører daglig udskillelse og ensomhed.

Forståelsen af fællesskaber som dynamiske og processuelle størrelser og begreberne 'inddragelse', 'indflydelse' og 'værdighed' kan bidrage med analytiske perspektiver til udforskning af børns fælles liv med hinanden. I sådanne analyser bliver det muligt at tilvejebringe praksisnær viden, der overgår diagnosens abstrakte sprogbrug og individualisering. Denne viden og forståelse af, hvad vanskelighederne handler om, peger på udviklingsmuligheder i praksis og væsentlige opmærksomhedspunkter i det pædagogiske arbejde i forhold til mennesker med handicap. Analyserne i artiklen peger på betydningen af, at de voksne involverer sig i børnenes fælles-skabelser og derigennem arbejder med den enkeltes mulighed for at blive inddraget $i$ og få indflydelse på det fælles på en vordig måde. 


\section{Litteratur}

Axel, E. (2009). Situeret projektering i et byggeprojekt. I: Nordisk Udkast, Nr. 1/2, s. 97-118.

Brinkmann, S. (2011). John Dewey og fællesskabelsens pædagogik. I: E. Jensen \& S. Brinkmann (red.). Fcellesskab i skolen. (151-170). København: Akademisk Forlag.

Dreier, O. (2008). Psychotherapy in Everyday Life. Cambridge: Cambridge University.

Dreier, O. (1999). Læring som ændring af personlig deltagelse i sociale kontekster. I: K. Nielsen \& S. Kvale (red.). Mesterloere: Løering som social deltagelse. (s.76-99) København: Hans Reitzels Forlag.

Dreier, O. (1997). Subjectivity and social practice. Aarhus: Centre for Health, Humanity and Culture. University of Aarhus.

Dreier, O. (1996): Ændring af professionel praksis på sundhedsområdet gennem praksisforskning. I: Jensen, Qvesel \& Fuur Andersen (red.). Forskelle og Forandring. (s. 113-140). Århus: Philosophia.

Harwood, V. \& Allan, J. (2014). Psychopathology at school. Theorizing mental disorder in education. London og New York: Routledge.

Hertz, S. (2010). "There is a crack in everything, that's how the light gets in". I: S. Brinkmann (red.). Det diagnosticerede liv. (s. 75-94). Aarhus: Klim.

Hjörne, E. \& Säljö, R (2004). "There Is Something About Julia": Symptoms, Categories, and the Process of Invoking Attention Deficit Hyperactivity Disorder in the Swedish School: A Case Study. In: Journal og Language, Identity \& Education, Volume 3, Issue 1, p. 1-24.

Holm Poulsen, C. (2017). Inklusion - muligheder og begrcensninger for deltagelse belyst gennem et børneperspektiv. Ph.d.-afhandling indleveret ved Institut for Kulturvidenskaber, Syddansk Universitet.

Holzkamp, K. (2013). Psychology from the standpoint of the subject: selected writings of Klaus Holzkamp. Basingstoke: Palgrave Macmillan.

Højholt, C., \& Schwartz, I. (2018). Elevsamspil, konflikter og udsathed i skolens fællesskaber. In C. Højholt, \& D. Kousholt (Ed.), Konflikter om børns skoleliv. København: Dansk psykologisk Forlag.

Højholt, C. (2016). Fra brugerperspektiver til konflikter om børns skoleliv. I: Nordiske Udkast, Vol. 43, Nr. 1, s. 27-49.

Højholt, C. \& Kousholt, D. (2012). Om at observere sociale fællesskaber. I: M. Pedersen, J. Klitmøller \& K. Nielsen (red.). Deltagerobservation. En metode til undersøgelse af psykologiske foenomener. (s.77-106). København: Hans Reitzels Forlag.

Højholt, C. (2005). Præsentation af praksisforskning. I: C. Højholt (red.). Forceldresamarbejde Forskning i foellesskaber. (s. 23-46). Dansk Psykologisk Forlag.

Højholt, C. (2001). Samarbejde om børns udvikling. København: Nordisk Forlag.

Kousholt, D. (2006). Familieliv fra et børneperspektiv. Deltagelse i foellesskaber. Ph.d.-afhandling ved Instituttet for psykologi, Roskilde Universitetscenter.

Kurth, M. (2013). Handicap hybrid - mellem den medicinske og den sociale model. I: I. S. Bonfils, B. Kirkebæk, L. Olsen \& S. Tetler (red.). Handicapforståelser mellem teori, erfaring og virkelighed. (s. 35-50). København: Akademisk Forlag.

Loewen \& Polland, (2010). The Social Justice Perspective. In: Journal of Postsecondary Education and Disability, Vol. 23, No. 1, p. 5-18.

Munck, C. (2017). Små børns fællesskabelse i en flertydig vuggestuepraksis. Ph.d.-afhandling ved Instituttet for Mennesker og Teknologi, Roskilde Universitetscenter.

Morin, A. (2007). Børns deltagelse og loering - på tvcers af almen- og specialpcedagogiske loerearrangementer. Ph.d.-afhandling fra DPU, Aarhus Universitet.

Nielsen, K \& Jørgensen, C.R. (2010). Patologisering af uro? I: S. Brinkmann (red.). Det diagnosticerede liv. (s.179-205). Aarhus: Klim.

Rasmussen, O.V. (2009). "Just in time" - hvordan overgå diagnoserne og skabe viden på stedet. I: Pcedagogisk Psykologisk Tidsskrift, Nr. 3, s. 167-187. 
Røn Larsen, M. (2011). Visitationsprocesser som betingelse for at arbejde med børn i vanskeligheder. I: C. Højholt (red.). Børn i vanskeligheder. Viborg: Dansk Psykologisk Forlag.

Stanek, A. (2012). Børns fællesskaber og fællesskabernes betydning. I: Nordisk udkast, Årg. 40, Nr.1, s. 38-51. 